\title{
The Method of Creative Learning of Higher Education Institute's Teachers in the Courses of Advanced Training and Retraining of Staff
}

\author{
Zukhra Karabaevna Ismailova ${ }^{1}$, Shaxlo Uktamovna Nurullaeva ${ }^{2}$, \\ Nozima Nurmaxammadovna Karimova ${ }^{3}$,Taxir Yuldashevich Abzairov ${ }^{4}$, \\ Shaxlo Kakhramonovna Sharopova ${ }^{5}$,
}

\footnotetext{
${ }^{1}$ Professor, Doctor of Pedagogical Sciences, Tashkent Institute of Irrigation and Agricultural Mechanization Engineers, Tashkent, Uzbekistan,

${ }^{2}$ Candidate of Pedagogical Sciences, Associate Professor, Karshi State University, Karshi, Uzbekistan,

${ }^{3}$ Associate Professor, Doctor of Philosophy $(\mathrm{PhD})$ in Pedagogical Sciences, Institute of Pedagogical Innovations, Management of Vocational Education and Retraining and Advanced Training of Teachers, Tashkent, Uzbekistan,

${ }^{4}$ Teacher, Termez branch of Nizami Tashkent State Pedagogical University, Termez, Uzbekistan,

${ }^{5}$ Teacher, Bukhara Institute of Irrigation and Agricultural Mechanization Engineers Bukhara Branch, Bukhara, Uzbekistan
}

\begin{abstract}
In this article, one of the global tasks of innovative development in the world is creativity, acmeological competence and professionalism of teachers around the world, including the creation of new ideas for creativity in people, the ability to solve complex processes, the creative approach to professional activities, the ability to take reasonable risks and professional competence. development of creativity, traditional and modern teaching methods through information and communication technologies and programs, socio-economic problems, such as intellectual resources, in order to create an appropriate role in the increase, the listed action strategy for the further development of the Republic of Uzbekistan includes the following areas: "further improvement of the lifelong education system, expanding opportunities for high-quality educational services, continuing the policy of training highly qualified specialists in accordance with modern requirements labor market. " In this regard, the importance of creativity of higher education teachers is emphasized.
\end{abstract}

Key words: creativity, teaching staff, professional activities, skills, professional competence, traditional and non-traditional methods, creativity, modern education.

Article Received: 16th October, 2020; Article Revised: 30th December, 2020; Article Accepted: 08th January, 2021

\section{I.Introduction}

The purpose of education is to describe the expected and anticipated outcomes that meet the needs of society and individual development. We can divide this into global (universal) and local (local) goals. Local goals are diagnostic, while global goals are undiagnosed and represent a high purpose. Global goals are built on the basis of the succession of local goals and are usually not achievable [Oleshkov M.Yu. et al., 2006. - 191 p].

The purpose of education is both internal and external. The external purpose of education is to develop productive forces based on specific historical conditions, such as government agencies, common culture, strengthening the legal relations of citizens and ensuring the welfare of the community based on the ethical and legal basis of community members. The internal purpose of education is characterized by the possibilities, development, ability to apply knowledge, skills and abilities in practice. It requires a purposeful force from the social environment, and these forces should be used to create material possibilities, to provide objective and social conditions, as well as to open new opportunities for the spiritual and moral improvement of the individual.

The modern system of education implies that one should abandon the strategy of reproductive learning with the primary goal of developing creativity and competence, and that it should be 
incorporated into the curriculum, including the knowledge, skills and abilities that meet the educational standards.

Creating creativity and focusing on innovations, analyzing problematic activities, understanding problems, developing their capacity is the goal of creative teaching, and it requires a lot of creative training. Thus, the purpose of the creative teaching of retraining and advanced training courses is to develop the creative competence and pedagogical skills of the students as well as to improve their creative thinking through creative teaching methods and design thinking techniques. The main objective of the course is to create favorable conditions for the comprehensive development of students. Creativity involves organizing the learning process, creating a creative learning process, enhancing the creative potential through creative teaching techniques and design thinking techniques, utilizing a variety of techniques to develop knowledge and skills, and actively participating in the development of student learning programs.

II. THE MAIN PART: The professional competence of the trainees of the courses of retraining and improvement of professional skills of teachers is important for their creativity development.Special knowledge by a professional competence specialist not every skill set but every independent direction by the integration of integrative knowledge and actions grip. Also, competence is a specialist knowledge enrichment, learning new information, important social understand the requirements, look for new information, find them recycling and use in their activities. The following is a brief overview of the qualities that are reflected on the basis of professional competence [Ismailova Z. et al.2019.-1175 p.].

1. Social competence - the ability to act in social relationships, have the skills, communicate with subjects in professional activities.
2. Special competence - preparation for the organization of professional and pedagogical activities, rational decision of professional and pedagogical tasks, realistic evaluation of the results of activities, consistent development of CRC, which are based on the competence of psychological, methodological, informational, creative, innovative and communicative competence. They represent the following content:

- psychological competence - to create a healthy psychological environment in the pedagogical process, to establish positive communication with students and other participants of the educational process, to be able to recognize and respond to various negative psychological conflicts in a timely manner;

- methodological competence methodical organization of the pedagogical process, the proper identification of forms of education or educational activities, the appropriate choice of methods and tools, the effective use of methods, the successful use of tools;

- information competence - search, collection, sorting, processing, and purposeful, efficient, efficient use of necessary, important, necessary, useful information in the information environment;

- creative competence - a critical, creative approach to pedagogical activity, ability to demonstrate their creative skills;

- innovative competence - promotion of new ideas, improvement of pedagogical process, improvement of quality of education, efficiency of educational process, their effective implementation;

- communicative competence - the ability to communicate warmly with all participants of the educational process, including students, to be able to listen to them and to have a positive impact on them.

\section{Personal competence -} consistently achieving professional growth, enhancing the qualification, demonstrating the internal capabilities of 
the professional activity.

4. Technological competence - the use of advanced technologies, enriching vocational and pedagogical knowledge, skills and abilities, the use of modern tools, techniques and technologies.

5. Extremely competent - ability to make wise decisions and behave in emergency situations (natural disasters, technological processes) and in case of pedagogical conflicts [Oleshkov M.Yu. et al., 2006. - 191 p].

Based on the opinions expressed, the creative competence of the students of higher education institutions was developed based on their professional competence (Figure 1.).

The main objectives of the formation of creative competence include:

- creating a learning environment that maximizes personality development;

- improvement of curricula aimed at developing creativity;

- Teaching and cognitive activities;

- Formation of self-education skills.

The level of learning content is based on people's knowledge of nature, society, humanity, their knowledge of the types of activities created as a result of human capabilities, and their ability to find new solutions to problems and to understand the world. The principles of education content formation include:

- scientific; reflect the latest achievements of social and cultural development based on primary knowledge;
- stage; each knowledge is based on the information previously received and derived from it;тарихийлик; илм фаннинг ушбу ёки бошқа сохалари ривожланиш тарихининг мактаб фан дастурларида кўпайиши, инсон амалиёти, таниқли олимларнинг фаолияти билан боғлиқ муаммолари билан боғлиқлиги;

- structurality; a structured approach to learning knowledge, skills that are designed to be integral to each other and to the whole system of human culture in the entire curriculum and school curriculum.

In line with these principles, the content of creative teaching of computer science, mathematics, and physics students in all training modules and retraining courses has been improved. Retraining and Upgrading of Teaching Staff The creativity of students in the areas of computer science, mathematics and physics:

$$
\text { special organizational and }
$$

pedagogical conditions for creative teaching;

- The module "Innovative Education Technologies and Pedagogical Competence" will be developed using techniques for improving the creativity of agriculture and water management, agriculture, electrification and automation of agriculture, etc. 


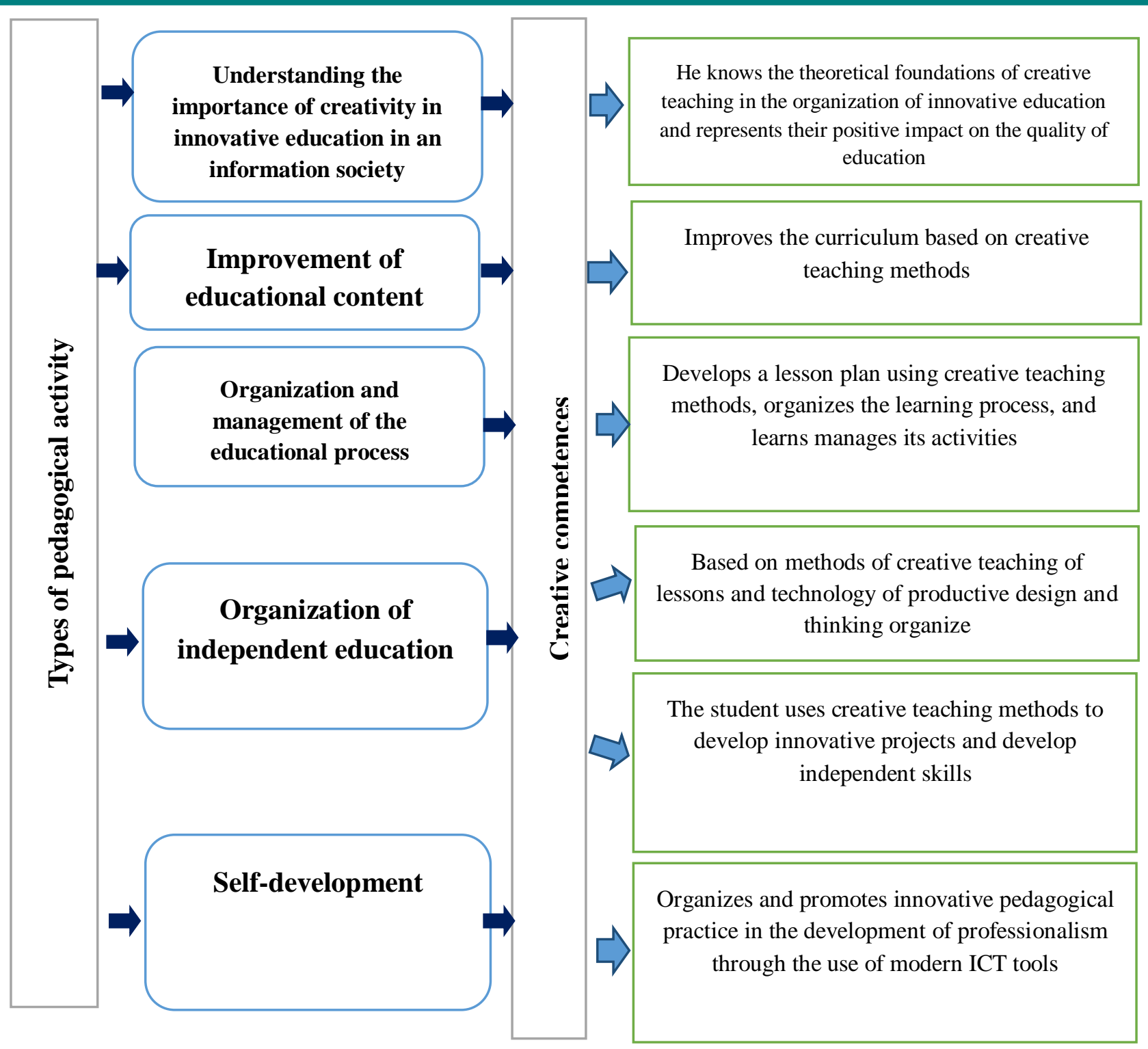

Figure 1.

\section{Creative competence of the teaching staff of higher education institutions}

III. DISCUSSION: Organizationalpedagogical conditions are a set of necessary and sufficiently important conditions related to the effectiveness of applying a particular methodology. Necessity of organizational and pedagogical conditions is expressed in the analysis of educational modules on pedagogical and psychological literature, work experience of students in higher educational institutions and retraining and advanced training of teachers. Listeners of the courses of agriculture and water management, mechanization of hydromeliorative works, electrification and automation of agriculture are required for the following courses:

$\checkmark$ Development of motivation of students in scientific and pedagogical activity;

$\checkmark$ Continuous self-analysis, control and management;

$\checkmark$ Using the results of pedagogical innovations and innovative activities in the development of teaching and methodological support;

$\checkmark$ Implementation of 
innovative and methodological projects based on a competent approach;

$\checkmark$ Using interactive and creative techniques and design and thinking technology in creating a creative learning environment.

We will focus on each of the above organizational and pedagogical conditions.

\section{The first condition.}

Motivation is the motivation that motivates every activity, process, and activity. That is why motivation is given to the development of professional creativity in the field of computer science, mathematics and physics. The listener uses a variety of ways to motivate his or her creativity. It is important that in each session, the listener experiences positive feelings, so that he or she can gain self-confidence and an interest in learning.

\section{The second condition.}

Thinking is the process and consequence of self-analysis on the subject of consciousness, behavior, inner mental behavior and states, their own experience, their personal structure. Through reasoning, the individual analyzes his actions (whether successful or not). This reflects the mechanisms of self-regulation and control. Reflection determines how consistent, purposeful, and effective the impact is, and how far the intended outcome has been achieved.

\section{The third condition.}

In order to fulfill the fifth condition of organizational and pedagogical conditions, it is necessary to create teaching and methodological support based on pedagogical innovation. Educationalmethodological support of the educational process includes the main textbooks, manuals and information resources for the educational activities of the trainees, ie a set of manuals and information resources for the organization of the educational process, a set of material and technical conditions for the educational process. Educational and methodological support of the educational process involves the development of teaching materials, the development of educational technologies and the introduction of innovative educational technologies. The educationalmethodical complex covers all normative and didactic aspects of teaching. It can consist of three parts.

The first part will cover the content of the educational and regulatory documents and provide examples of the documents.

The second part describes the teaching tools and their content.

The third section lists the controls. Improvement of the educationalmethodical complex allows students and students to work more on themselves. In the process of preparation for the training, the students will not only write a text in the form of textbooks, but will create educational technologies based on the new pedagogical technology of training using information and communication technologies. Listeners create electronic lessons, didactic materials and handouts using a variety of tutorials and Internet information. They will have more research to improve the quality of their workouts.

The teaching-methodical complex will achieve high results in strengthening didactic provision of teaching, wide introduction of modern pedagogical technologies, ensuring continuity of theoretical and practical lessons.

The educational and methodical complex is being enriched from year to year, which further enhances the quality of education.

\section{The fourth condition}

The concept of competence is a standard for evaluating professional development and professional maturity. It is used as a characteristic of the subject of work that describes specific job requirements or specific aspects of the subject's specific activities.

Prof. N.Muslimov provides that the competent professional possesses the knowledge, skills and abilities required to carry out professional activities and applies them at high levels [Muslimov 
N.A. Diss. 2007. - 275 p].

66). As Mr. Lebedev noted, a competent approach is a set of general principles aimed at defining learning objectives, choosing the content of education, organizing the learning process, and evaluating learning outcomes. These principles include the following rules [Lebedev O.E 2004. No. 5. pp. 3-1]:

1) The importance of education - the development of students' independent decision-making in various areas and activities using social experience based on their own experience;

2) content of education - didactically adapted social experience of the solution of cognitive, ideological, moral, political and other problems;

3) The meaning of the educational process is to create conditions for the students to develop their own knowledge, communication, organizational, spiritual and other issues that make up the educational content;

4) Assessment of learning outcomes is based on the analysis of the level of education received by a trainee.

The content, quality and qualification requirements for retraining and advanced training of teaching staff of higher education institutions provide the trainees with information, independent search, analysis, selection, processing and information related to their professional and professional activities through modern information and communication technologies. transfer and adaptation of necessary information, continuous development of independent cognitive activity, implementation of educational objectives in multimedia technologies Effective use of information in the case should have competence.

In the retraining and professional development courses, innovative and methodological projects (Figure 2) for the creation of creative ideas of the students in group work are carried out, ie presentation of their methodical work (Power Point, Ispring, etc.), mental maps, videos created by Mind Map. and video clips, educational software products, etc. [Pozilova Sh. 2018. P-45-54].

The features of the innovation and methodological project are as follows:

- Listeners identify problems based on their experience;

-Audience solves identified problems using creative teaching techniques and design thinking techniques (a number of large and small problems are identified and the best option is selected);

- Innovative-methodical project is implemented in 2 hours (lectures, practical lessons);

-The trainees learn the techniques of creative teaching during the lessons and apply it in their pedagogical practice.
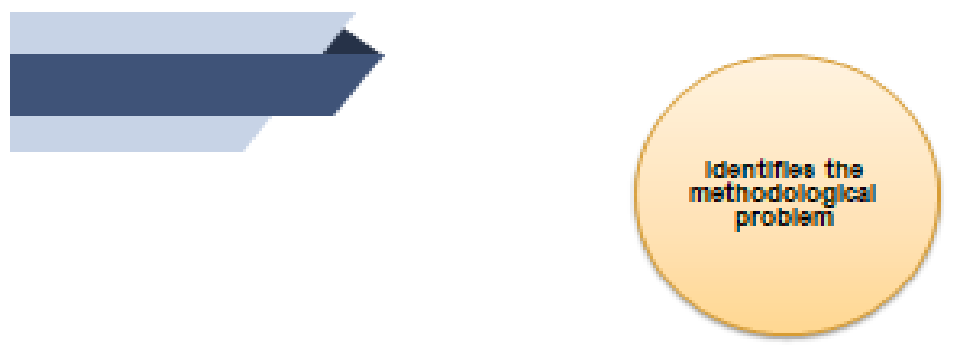


\section{Figure 2. Structure of innovative - methodical project}

\section{The fifth condition..}

Technology of design thinking along with methods of creative teaching play an important role in the development of creativity in computer science, mathematics and physics. One of the objectives of our research is to create a creative environment for students in computer science, mathematics and physics to teach subjects in science programs, that is, to have a clear learning resource at the end of training [Pozilova Sh. 2018. No. 2. p.p.49-55] "Design Thinking" is a technique that creates innovation. Its key element is deep understanding and observation of the problem. Design thinking technology is carried out in the following steps:

Understanding - Understanding a given problem situation. At this stage, problemoriented information is collected and sorted out. Listeners are asked why this information is a problem. All stages of the "design thinking" technology are based on this step. Of course, if you ask the audience what the problem is, they will certainly respond, but superficially, they try to hide human knowledge behind their inner feelings. If we want to find a solution to the real problem, we need to be interested in the inner voice of the audience. The real purpose of this stage should be to find the solution to the question "Why the above situation is a problem?"

Understanding is a basic part of the data, and you need to have a deeper understanding of how to handle, classify and apply it.

There are various interactive ways to do this. For example, "Cluster", "SWOT analysis", "Kyubing", "MindMap", etc.

Focus is the key point towards a specific problem. At the same time, we can divide the problem into smaller problems and solve a number of ideas. In order to create innovation, you need to find a solution to a problem that is not solved in another group, and copy the rest. We have to pick a problem that other group members think they have no solution to. It is in these issues that "Design-thinking" works at a high level. The main purpose of this phase is to clearly identify the problem. At the same time, it is important to ignore the first issue, rather to try to find a solution to the last issue. We use interactive methods such as SCAMPER, Plus, Minus, Interesting.

The prototyping stage. At the same time, the listeners are striving towards the goal, based on the answers to 
the questions. Finding answers to the questions at the top design stages would be a bit difficult. There are many things we can say as a prototype: a whiteboard filled with stickers, a roller coaster, and so on. As a result, we see in our listeners the knowledge that is derived from their inner feelings.

The test phase is generally similar to the Prototype phase, except that the results obtained in the above four stages are summarized and summarized.

Training using design thinking technology has been used in many developed countries. This is because lectures, seminars, and workshops are designed to encourage students to work harder. It can also make the exercise fun, not just listening to the listener for 80 minutes, but also showing the audience how to solve problems and solve problems on their own, as well as role-playing games. Listeners are not bored during such sessions and fully understand the new topic [Ismailova Z. K. et al., 2015. p.p. 218-220].

This environment is characterized by a favorable situation, acceptance and stimulation of any creative product. In this creative teaching group, a group of students in the field of computer science, mathematics and physics take part in activities such as discussing their interests, participating in discussions, encouraging and encouraging each other in statements and actions.

\section{IV.CONCLUCIONS:}

1. The aim of the creative training of students in the areas of computer science, mathematics and physics is to improve their professional competence and pedagogical skills, as well as to improve the creativity of students through creative teaching techniques and design thinking technology.

2. Based on the analysis of professional activity of the trainees of the courses of retraining and upgrading the pedagogical staff of the university, the composition of the creative competence of listeners in the field of agriculture and water management, mechanization of waterworks, electrification and automation of agriculture, etc.

3. Advanced training courses for pedagogical staff of higher education institutions improved methods of creative training for listeners in agriculture and water management, mechanization of waterworks, electrification and automation of agriculture, etc.

4. Organizational and pedagogical conditions for the creation of creative training in the field of computer science, mathematics and physics were developed for teachers and retraining courses.

5. The technique of step-by-step creative training based on the experience of the trainees of the retraining and advanced training courses for the teaching staff of the university.

6. Training and retraining courses for teachers of higher educational institutions have been developed training and methodical support for the organization of creative training in the fields of agriculture and water management, mechanization of water-meliorative works, electrification and automation of agriculture and others.

\section{REFERENCES:}

[1] Oleshkov M.Yu., Uvarov VM Современный образовательный process: основные понятия и термины // - M .: Company Sputnik + , 2006. - $191 \mathrm{p}$.

[2] Ismailova $\mathrm{Z}$. et al. The role of modern women in society and family.Opción, Año 35, Especial No.21 (2019): - p.p.734-751.

[3] Ismailova Z. K. and others. The role of the rules of design and planning of teaching technology at lectures in the preparation of future professional teachers // Pedagogy: traditions and innovations. - 2015 .- p.p. 218-220.

[4] Ismailova Z. K., Himmataliev D. O., Baybaeva M. Kh. The main issues of integration of education and 
production and ways to solve them // Pedagogy: traditions and innovations. - 2015 .- p.p. 216-218.

[5] Ismailova Z. K., Baybaeva M. Kh., Mukimov B. R. General patterns and principles of education // Young Scientist. - 2015. - No. 8. - p.p 934937.

[6] Muslimov NA, Usmanbaeva M., Mirsolieva M. Educationalmethodical complex on the module "Innovative educational technologies and pedagogical competence" - T: 2016. p. 147

[7] Obuhova L.F. Возрасная psychology: Учебник для вузов. M .: Vysshee obrazovanie, MPPPU, 2008.- 460p.

[8] 8.Yuzlikayeva E.R. Pedagogical monitoring in lichnostnoorientirovannom obrazovatelnom Processes and Systems Vysshego obrazovaniya: Monograph. Tashkent, 2007. - 188 p.

[9] Ismailova, Z., Choriev, R., Ibragimova, G., Abdurakhmanova, S., \& Abdiev, N. (2020). Competent model of Practice-oriented education of students of the construction profile. Journal of Critical Reviews. Innovare Academics Sciences Pvt. Ltd.

https://doi.org/10.31838/jcr.07.04.85

[10] Karabaevna, I. Z., Omonovich, K. D., Abduqunduzovna, B. G., Farmonovna, B. Z., \& Raxmatullaevna, R. L. (2020). Content of development of students educational activity in the context of mobilization of education. Journal of Critical Reviews. Innovare Academics Sciences Pvt. Ltd. https://doi.org/10.31838/jcr.07.05.77

[11] Karabaevna, I. Z., Omonovich, K. D., Murodillaevich, K. N., Normuminovna, S. U., \& Mahmatqulovich, A. O. (2020). Formation of a system of methods of technical thinking future engineers. Journal of Critical
Reviews. Innovare Academics

Sciences Pvt. Ltd. https://doi.org/10.31838/jcr.07.05.16 1

[12] Ismailova, Z. K., Khimmataliev, D. O., Khashimova, M. K., Baybaeva, M. K., \& Ergashev, B. B. (2020). Integrative approach to designing the content of secondary specialized vocational education. Opcion, 36(91), 25-41.

[13] Ismailova, Z., Choriev, R., Musurmanova, A., \& Aripjanova, M. (2020). Methods of training of teachers of university on advanced training courses. Journal of Critical Reviews. Innovare Academics Sciences Pvt. Ltd. https://doi.org/10.31838/jcr.07.05.85

[14] Karabaevna, I. Z., Riskulova, K., Ubaydullaevich, A. M., Turaevna, I. Y., \& Ravshanovna, P. N. (2020). The role of electronic pedagogical tools in higher education. Journal of Critical Reviews. Innovare Academics Sciences Pvt. Ltd. https://doi.org/10.31838/jcr.07.05.80

[15] Ismailova, Z., Choriev, R., Salomova, R., \& Jumanazarova, Z. (2020). Use of economic and geographical methods of agricultural development. Journal of Critical Reviews. Innovare Academics Sciences Pvt. Ltd. https://doi.org/10.31838/jcr.07.05.84

[16] Karabaevna, Z., Musurmanova, A., \& Xamroevich, R. (2019). Improving the competence of future vocational education teachers based on modular-rating

education. International Journal of Engineering and Advanced Technology, 9(1), 6903-6906. https://doi.org/10.35940/ijeat.A2997. 109119

[17] Ismailova, Z., \& Ergashev, B. (2019). New information and communication technologies in education system. In E3S Web of Conferences (Vol. 135). EDP 
Sciences.

https://doi.org/10.1051/e3sconf/2019 13504077

[18] Ismailova, Z., Khimmataliev, D., Khashimova, M., Fayzullaev, R., \& Sadikova, F. (2019). The role of modern women in society and family. Opcion, 35(Special Issue 21), 734-751

[19] Karabaevna, Z., \& Raximovich, B. (2019). The use of innovation technologies in the formation of students' professional competences. International Journal of Engineering and Advanced Technology, 9(1), 6898-6902. https://doi.org/10.35940/ijeat.A2996. 109119

[20] https://www.scopus.com/authid/detai 1.uri?authorId $=57218894251$

[21] E Farmonov, Z Ismailova, $\mathrm{T}$ Abdilaev and $\mathrm{F} \quad$ Farmonova ${ }^{1}$ Mechanized sowing of seeds of desert fodder plants. IOP Conference Series: Materials Science and $\underline{883}$, International Engineering, Volume Scientific Conference Construction Mechanics, Hydraulics and Water Resources Engineering (CONMECHYDRO 2020) 23-25 April 2020,

[22] B Khasanov, N Vatin, Z Ismailova and $\mathrm{T}$ Mirzaev. Physical modification of concrete mix and concrete. IOP Conference Series: Materials Science and Engineering, Volume

$\underline{883}$, International Scientific Conference Construction Mechanics, Hydraulics and Water Resources Engineering (CONMECHYDRO 2020) 23-25 April 2020,

[23] Zukhra Ismailova, Shirinboy Olimov, Durdona Mustafoeva, Yulduz Yarmanova, Nargiza Temirkulova. (2020). Technology Of Diagnostic Level Of Development Of Professional Competence Of Pedagogical Personnel In The System Of Training. International
Journal of Advanced Science and Technology, 29(7), 3337-3343. Retrieved from http://sersc.org/journals/index.php/IJ AST/article/view/21886

[24] Zukhra Ismailova, Olim Turakulov, Shakhnoz Samieva, Igamberdi Tufliev, Abdakim Mamataliev. (2020). Technology, Content, Form And Methods Of Independent Work Of Students In Modern Conditions. International Journal of Advanced Science and Technology,29(7), 33443348. Retrieved from

[25]

http://sersc.org/journals/index.php/IJ AST/article/view/21887

[26] Pozilova Sh. Organizational and pedagogical terms of using creative learning at courses of improvement of pedagogical staff // American Journal of Research (ISSN 25735624). Journal. - USA, 2018. P-4554. (Impact factor 3.57, IFS 4.7 / UIF 3.8). DOI: https://doi.org/ 10.26739 / 2573-5616-2018-3-1-7.

[27] Pozilova Sh. Organizationalnopedagogical application of creative methods of teaching on modern courses // Modern education (Современное образование). - Т.: Print Line Group. 2018. - No. 2. S.49-55.

[28] Khimmataliev D., Khakimov J., Daminov O., Rakhmatova F. Criteria and indicators for assessing the level of professional training of future teachers of vocational training at a training module // Journal of critical reviews. ISSN - 2394-5125. Vol 7, Issue 5, 2020 - p. 428-431. doi:10.31838/jcr.07.05.89

[29] Khimmataliev D.O. Integration of pedagogical and technical knowledge in the diagnosis of preparation for professional activity. Monograph. Tashkent, Uzbekistan, 2018 - 168 p.

[30] Khimmataliev D.O. Integration of pedagogical and technical knowledge in the diagnosis of professional 
training: Doctorate in Pedagogical Sciences (DSc) diss. avtoref. - T .: 2018. -70 b 120

[31] Khimmataliev D.O., Baybaeva M.X. Use of modular training opportunities. Monograph. - T.: Uzbekistan, 2017. - 132 p.

[32] Khimmataliev D.O. Integration of scientific knowledge in preparation for the professional activities of future teachers of vocational education // School of the future. Moscow, 2016. No. 6. -S. 50-54.

[33] Olimov K. T. et al. Competent training of future specialists on the basis of acmelogical approach //Journal of Critical Reviews. - 2020.

- T. 7. - №. 15. - P. 2476-2483.

[34] Olimov K. T et al..Introduction of dual training in the system of continuous professional education. European Journal of Research and Reflection in Educational Sciences// -2020. Volume 7 Number 12, 2019 Part VI. P. 509-512

[35] Olimov K. T. et al. Teaching Special Subjects for Students with Disabilities in Preparation for the Profession by Using Innovative Educational Technologies //International Journal of Innovative Technology and Exploring Engineering (IJITEE). - 2019. - T. 9. - C. 425-429. 